\title{
Identifikasi Morfologi Mikroflora pada Saluran Pencernaan Itik Magelang
}

\section{Identification of Microflora Morphology in the Digestive Tract of Magelang Ducks}

\author{
W. T. Nugraha ${ }^{1}$, M. S. I. Pradipta ${ }^{1}$, P. B. Pramono ${ }^{1}$, A. S. Soekarno ${ }^{2}$, B. Kusuma ${ }^{3}$ \\ ${ }^{1}$ Program Studi Peternakan, Fakultas Pertanian, Universitas Tidar \\ ${ }^{2}$ Program Studi Ilmu dan Industri Peternakan, Fakultas Peternakan, Universitas Gadjah Mada \\ ${ }^{3}$ Program Studi Akuakultur, Fakultas Perikanan dan Ilmu Kelautan, Universitas Jenderal Soedirman \\ Corresponding Author : mncpradipta@gmail.com
}

\begin{abstract}
This study aims to identify the microflora found in the digestive tract of Magelang ducks. Magelang duck samples were obtained at the location of semi-intensive maintenance farms in Secang District, Magelang. The isolates were collected from the cecum and contents of the Magelang duck cecum. The data taken in this study were colony color, colony shape, colony edge shape, cell shape, motility, spore formation, and gram staining. The data analysis used was descriptive. Based on the results of morphological observations that have been carried out, all the isolates have a shiny milky white colony color, puncture shape, flat edge shape, non-motile, negative $\mathrm{CO}_{2}$ production, gram-positive paint, and negative spore production. The conclusion from this study is that the bacterial isolation results obtained in the digestive tract of Magelang ducks are gram-positive bacteria. So that further tests are needed to determine the potential of probiotic candidates.
\end{abstract}

Key words: Magelang ducks, microflora, morphology, poultry

\begin{abstract}
ABSTRAK
Penelitian ini bertujuan untuk mengetahui mikroflora yang terdapat pada saluran pencernaan itik Magelang. Sampel itik Magelang didapatkan pada lokasi peternakan pemeliharaan semi-intensif/umbaran di Kecamatan Secang, Magelang. Pengambilan isolat didapatkan dari sekum dan isi sekum itik Magelang. Data yang diambil dalam penelitian ini adalah warna koloni, bentuk koloni, bentuk tepian koloni, bentuk sel, motilitas, pembentukan spora dan pewarnaan gram. Analisis data yang digunakan menggunakan analisis deskriptif. Berdasarkan hasil pengamatan morfologi yang telah dilakukan, dari seluruh isolat memiliki warna koloni putih susu mengkilat, bentuk bacil, bentuk tepian rata, non-motil, produksi $\mathrm{CO}_{2}$ negatif, cat gram positif dan produksi spora negatif. Kesimpulan yang didapatkan dari penelitian ini yaitu hasil isolasi bakteri yang didapatkan dalam saluran pencernaan itik Magelang adalah bakteri gram positif. Sehingga diperlukan uji lanjut untuk mengetahui potensi kandidat probiotik.
\end{abstract}

Kata Kunci: itik Magelang, mikroflora, morfologi, unggas

\section{PENDAHULUAN}

Itik Magelang (Anas platyhyncos) merupakan itik tipe petelur dan pedaging (dwiguna) asli Magelang, Jawa Tengah, Indonesia (Subiharta dan Hermawan, 2015). Itik Magelang memiliki ciri leher yang relatif panjang, berbulu cokelat, dan memiliki tanda khusus berupa warna putih menyerupai kalung di leher sehingga sering disebut itik kalung. Sedangkan sifat kuantitatifnya untuk bobot badan itik jantan dewasa 1,8-2,5 kg dan betina dewasa 1,5-2,0 kg (Dinas Peternakan dan Perikanan Kabupaten Magelang, 2013). Produksi telur itik Magelang berkisar 130-170 butir/ tahun (Haqiqi, 2008). Rerata jumlah telur yang dihasilkan dari itik yang dipelihara secara semi intensif berkisar antara 100 sampai 125 butir telur/ekor dalam 1 periode pemeliharaan (BPTP Sumatera Selatan, 2002). Rahayu et al. (2019) menambahkan bahwa itik yang dipelihara secara semi intensif menghasilkan telur sebanyak 125 butir/30 hari dengan jumlah itik 20 ekor.

Rahayu et al. (2019) dalam penelitiannya mengatakan bahwa pola pemeliharaan semi intensif pada itik identik dengan kurang konsisten dalam pemberian pakan baik jenis maupun kandungan nutrien pakan yang diberikan. Rahayu et al. (2019) juga mengatakan bahwa pola pemeliharan tersebut akan mempengaruhi produktivitas itik, karena rendahnya pengawasan atau kontrol dalam hal kesehatan ternak dan pemberian pakan yang berkaitan dengan pertumbuhan itik tersebut. Perbedaan konsistensi pemberian pakan pada pemeliharaan semi intensif dan intensif baik kualitas kandungan nutrien maupun jenis pakan yang dikonsumi ini 
diduga mempengaruhi mikroflora usus. Hal ini didukung oleh pernyataan Prasetyo (2019) yang menyatakan bahwa salah satu factor yang mempengaruhi microflora usus adalah pakan dan pemberiannya. Rahayu et al. (2019) dalam penelitiannya juga mengatakan bahwa, pola pemeliharaan semi intensif memiliki ciri khas yaitu itik bisanya diumbar lalu pakan tetap diberikan kepada ternak, biasanya 1 kali sehari). Ketika pemeliharaan diumbar maka akan timbul variasi konsumsi pakan dan nutrient intake yang diperoleh oleh itik, karena itik diberikan kesmepatan untuk bebas mencari pakan (Rahayu et al., 2019).

Usus merupakan pusat dari kesehatan saluran pencernaan setiap makhluk hidup. Di dalam usus terdapat berbagai macam mikroflora baik bakteri, fungi, yeast yang apabila dalam kondisi yang seimbang dapat memberikan pengaruh positif terhadap kesehatan. Kondisi mikroflora usus yang seimbang membantu pertumbuhan vili-vili usus sehingga meningkatkan fungsi barier usus sebagai pertahanan tubuh terhadap infeksi bakteri patogen (Sri-Harimurti, 2009; Rinttilä dan Apajalahti, 2013). Beberapa penelitian menyebutkan bahwa keberadaan mikroflora usus yang menguntungkan mampu meningkatkan produksi asam lemak rantai pendek berupa propionat dan butirat. Asam lemak rantai pendek merupakan prekursor utama dalam menstimulasi proliferasi epitelium intestinal (Gunal et al., 2006; Sri-Harimurti dan Rahayu, 2009; Sri-Harimurti et al., 2013; Ariyadi dan SriHarimurti, 2015). Di samping itu pertumbuhan vili-vili usus yang semakin lebar dan panjang juga meningkatkan fungsi absorpsi nutrien (Sieo et al., 2005; Sri-Harimurti et al., 2017) yang kemudian lebih jauh memberikan pengaruh terhadap performan itik Magelang.

Itik yang sehat umumnya dicirikan memiliki usus yang berfungsi dengan baik. Hal ini penting dalam mengkonversi pakan yang efisien untuk pemeliharaan dan untuk pertumbuhan atau produksi. Salah satu ciri terpenting dari usus yang berfungsi dengan baik adalah keseimbangan populasi bakterinya (Maki et al., 2019). Populasi mikroba dalam usus tergantung pada jenis, umur, pakan, dan lokasi geografis. Secara umum, bakteri usus dapat dibagi menjadi spesies yang berpotensi berbahaya (patogen) dan yang menguntungkan bagi itik (Anadón et al., 2019).

Pakan yang dikonsumsi dan dicerna oleh itik dapat mengandung nutrisi, non-nutrisi, dan organisme menguntungkan dan bakteri patogen.
Oleh karena itu, usus menjadi organ utama yang berpotensi terpapar patogen. Biasanya, lumen usus mengandung pakan dan konstituennya. Komponen apa pun yang tertelan bersamaan dengan pakan dapat mempengaruhi perkembangan dan kesehatan saluran usus (Yadav and Jha, 2019). Tao et al. (2019) juga menyatakan bahwa dalam usus itik petelur terdapat keanekaragaman mikroflora usus yang mempengaruhi produktivitas itik, diantaranya adalah golongan bakteri Bacteroidetes, Proteobacteria, dan Firmicutes. Golongan yang paling dominan adalah Proteobacteria. Dalam tingkat genus, terdapat mikrobia dalam golongan Lactobacillus dimana nantinya bakteri ini dapat menjadi bakteri yang mendominasi di dalam usus bebek. Bakteri golongan Lactobacillus dapat memperbaiki kondisi saluran usus baik secara morfologi, kondisi microbiota, dan mempertahankan produktivitas itik terutama pada saat terkena cekaman panas (heat stress) (Song et al., 2014; Faselah et al., 2016).

Berdasarkan uraian di atas maka itik Magelang yang dipelihara dengan sistem semiintensif akan dimungkinkan memiliki mikroflora yang menguntungkan bagi itik Magelang. Oleh kerena itu penelitian ini menarik untuk dilakukan bertujuan untuk mengidentifikasi mikroflora yang terdapat pada saluran pencernaan itik Magelang.

\section{MATERI DAN METODE}

Sampel itik Magelang didapatkan pada lokasi peternakan dengan pemeliharaan semiintensif/umbaran di Kecamatan Secang, Magelang. Data yang diambil dalam penelitian ini adalah data morfologi yang meliputi bnetuk koloni, bentuk sel, motilitas, pembentukan spora dan pewarnaan gram.

Sebanyak $10 \mathrm{~g}$ sekum dan isi sekum Itik Magelang diambil secara aseptis. Metode yang dilakukan adalah mengetahui morfologi mikroflora yang ada di dalam saluran pencernaan itik Magelang. Metode pewarnaan Gram dilakukan dengan metode pewarnaan (Seely et al., 2001). Data morfologi koloni bakteri yang diperoleh dianalisis secara deskriptif serta disajikandalam bentuk tabel dan gambar (Thompson, 2009).

\section{HASIL DAN PEMBAHASAN}

Kelancaran proses pencernaan nutrien ransum sangat dipengaruhi oleh mikroflora saluran pencernaan. Hal ini merupakan andil dari 
mikroflora yang ada disaluran pencernaan yang akan membentuk enzim pencernaan. Untuk memperlancar metabolisme pada tubuh dibutuhkan perkembangan bakteri utama (bakteri menguntungkan) pada saluran pencernaan (Eli et $a l$, 2018). Kinerja saluran pencernaan akan optimal apabila pertumbuhan bakteri pathogen dapat ditekan oleh aktivitas bakteri nonpatogen. Penyerapan nutrien yang optimal akan mendukung pembentukan daging yang dapat dilihat dari pertambahan bobot badan (Aprilianti et al., 2017).

Umumnya bakteri yang ada di alam terdapat dalam berbagai jenis. Untuk mengetahui sifat pertumbuhan maupun morfologi maka bakteri- bakteri tersebut perlu dipisahkan masingmasing. Hal inilah yang disebut dengan kultur murni yaitu sel-sel satu spesies atau satu galur pada suatu biakan bakteri (Fardiaz, 1989). Setiap koloni yang tumbuh secara dominan pada saluran pencernaan itik diambil dan ditumbuhkan pada media sebagai dasar dalam identifikasi. Untuk mendapatkan isolate bakteri yang diambil dari isi sekum dan sekum diberikan kode seperti tersaji pada Tabel 1. Isolasi bakteri yang didapatkan dari penelitian berasal dari sampel saluran pencernaan itik Magelang. Bagian yang diambil adalah bagian sekum dan isi sekum dapat dilihat di Tabel 1. Dari kedua bagian tersebut kemudian ditumbuhkan pada media. Isolasi bakteri adalah proses pemindahan atau pengambilan mikroba dari lingkungannya di alam dan ditumbuhkan sebagai biakan murni dalam medium buatan (Dewi, 2008). Hasil isolasi bakteri tersebut dapat dilihat pada Gambar 1.

Pengamatan morfologi yang dilakukan terhadap isolat yang diambil meliputi bentuk sel, motilitas, pembentukan spora, pewarnaan gram positif atau negatif. Hasil pengamatan morfologi dapat dilihat pada Tabel 2.

\section{Tabel 1. Kode dan Asal Isolat}

\begin{tabular}{lcc}
\hline No & Kode Isolat & Asal Isolat \\
\hline 1. & Is1 & Isi Sekum \\
2. & Is2 & Isi Sekum \\
3. & Is3 & Isi Sekum \\
4. & Is4 & Isi Sekum \\
5. & Is5 & Isi Sekum \\
6. & Is6 & Isi Sekum \\
7. & S1 & Sekum \\
8. & S2 & Sekum \\
9. & S3 & Sekum \\
10. & S4 & Sekum \\
11. & S5 & Sekum \\
12. & S6 & Sekum
\end{tabular}

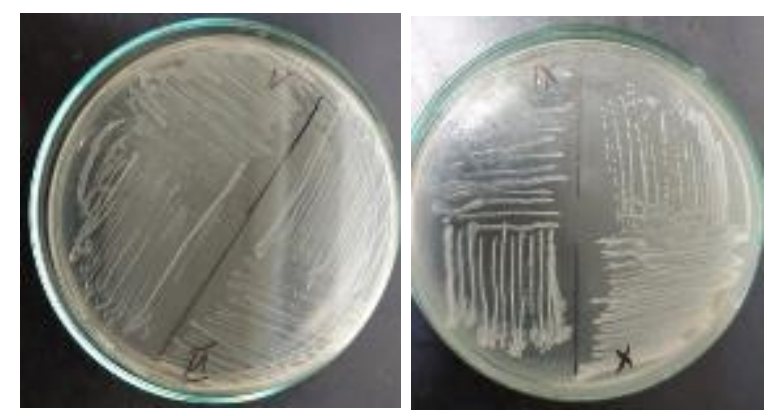

Gambar 1. Hasil isolasi bakteri saluran pencernaan itik Magelang

Berdasarkan hasil pengamatan morfologi yang telah dilakukan, dari seluruh isolat memiliki warna koloni putih susu mengkilat, bentuk bacil, bentuk tepian rata, non-motil, produksi $\mathrm{CO}_{2}$ negatif, cat gram positif dan produksi spora negatif.

Tabel 2. Hasil pengamatan koloni bakteri saluran pencernaan itik Magelang

\begin{tabular}{cccc}
\hline Kode Isolat & Warna Koloni* & Bentuk Koloni* & Bentuk Tepian Koloni* \\
\hline Is1 & Putih susu mengkilat & Bacil & Rata \\
Is2 & Putih susu mengkilat & Bacil & Rata \\
Is3 & Putih susu mengkilat & Bacil & Rata \\
Is4 & Putih susu mengkilat & Bacil & Rata \\
Is5 & Putih susu mengkilat & Bacil & Rata \\
Is6 & Putih susu mengkilat & Bacil & Rata \\
S1 & Putih susu mengkilat & Bacil & Rata \\
S2 & Putih susu mengkilat & Bacil & Rata \\
S3 & Putih susu mengkilat & Bacil & Rata \\
S4 & Putih susu mengkilat & Bacil & Rata \\
S5 & Putih susu mengkilat & Bacil & Rata \\
S6 & Putih susu mengkilat & Bacil & Pat
\end{tabular}

*Hasil pengujian di Laboratorium Teknologi Hasil Ternak, Fakultas Peternakan, Universitas Gadjah Mada, Yogyakarta (2020) 
Tabel 3. Hasil pengamatan morfologi bakteri saluran pencernaan itik Magelang

\begin{tabular}{ccccc}
\hline Kode Isolat & Motilitas* & Produksi $\mathrm{CO}_{2} *$ & Cat Gram* & Pembentukan Spora* \\
\hline Is1 & Non-motil & Negatif & Positif & Negatif \\
Is2 & Non-motil & Negatif & Positif & Negatif \\
Is3 & Non-motil & Negatif & Positif & Negatif \\
Is4 & Non-motil & Negatif & Positif & Negatif \\
Is5 & Non-motil & Negatif & Positif & Negatif \\
Is6 & Non-motil & Negatif & Positif & Negatif \\
S1 & Non-motil & Negatif & Positif & Negatif \\
S2 & Non-motil & Negatif & Positif & Negatif \\
S3 & Non-motil & Negatif & Positif & Negatif \\
S4 & Non-motil & Negatif & Positif & Negatif \\
S5 & Non-motil & Negatif & Positif & Negatif \\
S6 & Non-motil & Negatif & Positif & Negatif \\
\hline
\end{tabular}

*Hasil pengujian di Laboratorium Teknologi Hasil Ternak, Fakultas Peternakan, Universitas Gadjah Mada, Yogyakarta (2020)

Seluruh hasil pengujian motilitas isolat, produksi $\mathrm{CO}_{2}$, cat gram dan pembentukan sproa didapatkan bahwa secara berturut-turut non-motil, negatif, positif dan negatif sesuai terlihat pada Tabel 3. Uji motilitas dilakukan untuk mengamati bakteri motilitas dan penyebaran pertumbuhan bakteri di sepanjang garis pada media. Hasil tersebut dapat menjadi indikasi isolate bakteri yang didapatkan merupakan kandidat bakteri asam laktat. Hal ini sesuai dengan hasil penelitian yang dilakukan oleh Yayuk (2020).

Hasil penelitian ini (Tabel 2) mirip dengan penelitian Mutmainnah (2013), yang juga memperoleh hasil negatif (non-motil) pada karakterisasi bakteri asam laktat yang diperoleh dari saluran pencernaan ayam kampung. Mutmainnah (2013) menambahkan bahwa bakteri dengan ciri-ciri morfologi berwarna koloni putih susu, bentuk batang (basil), gram positif dan tepian rata merupakan bakteri asam laktat dari genus Lactobacillus. Surono (2004) juga menambahkan bahwa variasi dari karakteristik bakteri asam laktat umum terjadi. Namun sifatnya secara umum adalah sebagai bakteri gram positif. Bakteri asam laktat yang berbentuk batang (basil) biasanya merupakan golongan dari Lactobacillus dan yang berbentuk kokus termasuk golongan Lactococcus, Streptococcus.

Hasil penelitian ini menunjukan bahwa karakteristik morfologi bakteri yang diamati menghasilkan $\mathrm{CO}_{2}$ (Tabel 2). Hasil penelitian ini mirip dengan penelitian Asriani (2006) yang melaporkan bahwa bakteri asam laktat menghasilkan produk metabolit berupa $\mathrm{CO}_{2}, \mathrm{H}_{2} \mathrm{O}_{2}$, dan asam organik. Harlina (2014) juga menambahkan bahwa $\mathrm{CO}_{2}$ juga dapat dihasilkan dari penguraian urea menjadi $\mathrm{CO}_{2}$ dan $\mathrm{NH}_{3}$ oleh aktivitas enzim urease.
Hasil penelitian ini menunjukan bahwa karakteristik morfologi bakteri yang diamati tidak menghasilkan atau tidak terjadi pembentukan spora (Tabel 2). Harlina (2014) menyatakan bahwa kemampuan pembentukan asam laktat ini dimiliki oleh kolompok bakteri asam laktat (BAL), ciri-ciri yang dimiliki termasuk dalam gram positif dan tidak membentuk spora. Malaka dan Laga (2005) juga menambahkan bahwa secara fisiologis bakteri asam laktat masuk sebagai bakteri gram positif yang tidak membentuk spora, dengan asam laktat sebagai produk utama dari fermentasi karbohidrat.

Pada pengecatan gram didapatkan hasil warna ungu yang menunjukkan bahwa bakteri tersebut memiliki gram postif. Fitri dan Yasmin, (2011) menyatakan bahwa bakteri gram negatif memiliki struktur dinding sel dengan kandungan lipid yang tinggi sedangkan bakteri gram positif memiliki struktur dinding sel dengan kandungan peptidoglikan yang tebal. Hasil pewarnaan bakteri dapat dilihat pada Gambar 2 berikut ini.

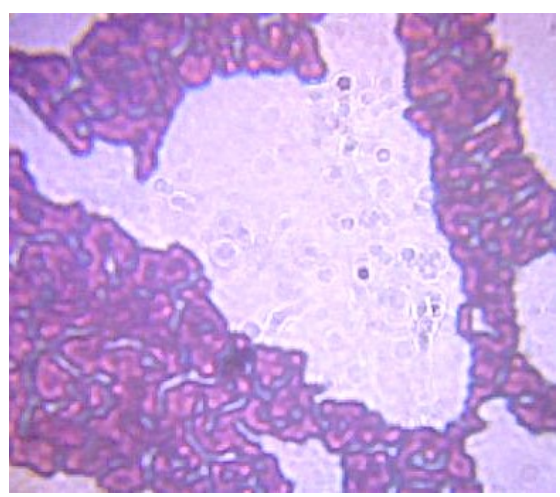

Gambar 2. Pewarnaan bakteri saluran pencernaan itik Magelang. 
Hasil warna ungu yang terbentuk disebabkan karena bakteri gram positif mampu mempertahankan komplek warna ungu kristal iodium sampai akhir uji (sel tampak biru gelap atau ungu). Berbeda dengan bakteri gram negatif pada saat pembilasan dengan alcohol yang akan kehilangan wara komplek warna ungu kristal sehingga sel terlihat berwarna merah muda oleh akibat pewarnaan tandingan dengan adanya safranin (Siregar et al., 2018)

\section{KESIMPULAN}

Berdasarkan penelitian ini didapatkan hasil bahwa isolasi bakteri yang didapatkan dalam saluran pencernaan itik Magelang adalah bakteri gram positif.

\section{DAFTAR PUSTAKA}

Anadón, A., I. Ares, M.R. Martínez-Larrañaga, and M.A. Martínez. 2019. Prebiotics and Probiotics in Feed and Animal Health. probiotics in feed and animal health, Nutraceuticals in Veterinary Medicine. 261-285.

Aprilianti, E., I. Mangisah, dan V.D.Y.B Ismadi. 2017. Pengaruh penggunaan limbah kecambah kacang hijau terhadap kecernaan protein kasar, kecernaan serat kasar dan pertambahan bobot badan itik Magelang. Agromedia 35 (2): 33-40.

Asriani. 2006. Kajian efek sinergi antimikroba metabolit bakteri asam laktat dan monoasilgliserol minyak kelapa terhadap bakteri patogen. Desertasi. Sekolah Pascasarjana Institut Pertanian Bogor.

BPTP Sumatera Selatan. 2002. Pemeliharaan ternak itik secara intensif. Lembar Informasi Pertanian. No.06/SR/2002.

Dewi, I. M. 2008. Isolasi bakteri dan uji aktifitas kitinase termofilik kasar dari sumber air panas tinggi raja, Simalungun, Sumatera Utara. Tesis. Sekolah Pascasarjana Universitas Sumatera Utara, Medan.

Eli, S., Tuti W., Rosita L. B. Dan Abun. 2018. Pengaruh pemberian kitosan terhadap mikroflora saluran cerna itik tegal. Jurnal Pendidikan Matematika dan IPA. 9 (2): 119-126.

Faselah, J.M., Y. Wesam Altaher, P. Shokryazdan, R. Ebrahimi, M. Ebrahimi, Z. Idrus, V. Tufarelli, and J. B. Liang. 2016. Dietary supplementation of a mixture of Lactobacillus strains enhances performance of broiler chickens raised under heat stress conditions. Int. J. Biometeorol. 60: 1099-1110.

Fitri, L dan Y. Yasmin. 2011. Isolasi dan pengamatan morfologi koloni bakteri kitinolitik. Jurnal Ilmiah Pendidikan Biologi, Biologi Edukasi 3 (2): 20-25.

Harlina. 2014. Isolasi dan karakterisasi bakteri asam laktat dari usus itik (Anas Domestica). Skripsi. Jurusan Sains Biologi pada Fakultas Sains dan teknologiuniversitas Islam Negeri Alauddin Makassar.

Maki, J.J., C.L. Klima, M.J. Sylte, and T. Looft. 2019. The microbial pecking order: utilization of intestinal microbiota for poultry health. Microorganisms. 7(10):E376.

Malaka, R dan A. Laga. 2005. Isolasi dan identifikasi Lactobacillus bulgaricus strain Ropy dari yogurt komersial. J. Sains dan Teknotogi 5 (1): 51-58.

Mutmainnah, H. 2013. Isolasi dan karakterisasi bakteri probiotik dari saluran pencernaan ayam kampung Gallus domesticus. Skripsi. Fakultas Matematika dan Ilmu Pengetahuan Alam, Universitas Hasanuddin.

Prasetyo, H.F.D. 2019. Pengaruh penambahan daun bidara (Ziziphus mauritiana Lamk) pada ransum ayam pedaging sebagai pengganti antibiotik terhadap mikrobia pada usus. Skripsi. Fakultas Peternakan Universitas Brawijaya. Malang.

Rahayu, T. P., L. Waldi, M. S. I. Pradipta, dan A. N. Syamsi. 2019. Kualitas ransum itik Magelang pada pemeliharaan intensif dan semi intensif terhadap bobot badan dan produksi telur. Bulletin of Applied Animal Research 1 (1): 8-14.

Risna, Y. K., S. Harimurti, Wihandoyo, and Widodo. 2020. Screening for probiotic of lactic acid bacteria isolated from the digestive tract of a native Aceh duck (Anas platyrhynchos). Biodiversitas 21 (7): 30013007.

Siregar, C.S., Erina dan M. Abrar. 2018. Isolasi Escherichia coli pada telur puyuh 
(Coturnix-coturnix japonica) yang gagal menetas di peternakan Desa Garot Kecamatan Darul Imarah Aceh Besar. JIMVET. 2(1):161-169.

Song, J., K. Xiao, Y. L. Ke, L. F. Jiao, C. H. Hu, Q. Y. Diao, B. Shi, and X. T. Zou. 2014. Effect of a probiotic mixture on intestinal microflora, morphology, and barrier integrity of broilers subjected to heat stress. Poult. Sci. 93:581-588.

Surono, I. S. 2004. Probiotik susu fermentasi dan kesehatan. Tri Cipta Karya. Jakarta.
Tao, Z., W. Xu, C. Zhu, S. Zhang, Z. Shi, W. Song, H. Liu, and H. Li. 2019. Effects of ammonia on intestinal microflora and productive performance of laying ducks. Poultry Science 98: 1947-1959.

Thompson CB. 2009. Descriptive data analysis. Air Med J. 28 (2): 56-59.

Yadav S. dan R. Jha. 2019. Strategies to modulate the intestinal microbiota and their effects on nutrient utilization, performance, and health of poultry. Journal of Science and Biotechnology 10(2):2-11. 